\title{
Assessment of Heavy Metals Level of River Kaduna at Kaduna Metropolis, Nigeria
}

\author{
${ }^{* 1}$ ABUI, YM; ${ }^{2}$ EZRA, V; ${ }^{3}$ BONET, RA; ${ }^{4}$ AMOS, B \\ $1 \& 2$ Dept. of Environmental Management, Kaduna State University. \\ 3 Dept. of geography, Kaduna State University \\ 4 Department of Horticulture and Land Scape. \\ Federal Collage of Forestry and Mechanization. Afaka, Kaduna \\ abuimbayunana@yahoo.com (08097441440)
}

\begin{abstract}
River Kaduna which serves as source of water for farming, domestic and industrial uses suffers enormous pollution as a result of industrial activities and other anthropogenic sources of contamination. The study determines the concentration of some selected heavy metal of the surface waters of River Kaduna, examines the pollution status and the implications of the heavy metal pollution on human health and the environment. The water Samples were collected using Grab method along the River Kaduna at five points - Bypass, Barnawa, Down quarters, Kakuri - Makera drains and Kudendan. Six samples during the rainy season and another during the dry season. The samples were taken to the laboratory and analyzed for chromium, Arsenic, Iron, copper, Berium, Aluminium, Cadmium, Cyanide and zinc using Atomic Absorption Spectrophotometer. The results obtained from the analysis were compared with the World Health Organization (WHO) recommended standards in order to ascertain the magnitude of pollution and the quality of the water. The concentrations of the metals were observed to be higher than WHO acceptable limits. This revealed that the river have become contaminated by heavy metals discharged into the river especially from the industries and municipal wastes and may cause serious ecological and health hazards. The paper recommends that there should be proper monitoring of effluents, there is the need for mass education of people on the impact of indiscriminate waste discharge on the water quality, and a regular schedule for sampling tributary streams and the main river Kaduna should be established. ( ) JASEM

https://dx.doi.org/10.4314/jasem.v21i2.16
\end{abstract}

Keywords: Heavy metals, Pollution, Hazard, Environment, Industrial Wastes and Effluents.

In Natural aquatic ecosystems, metals occur in low concentrations, normally at the nanogram to microgram per liter level. In recent times, however, the occurrence of metal contaminants, especially heavy metals in excess of natural loads has become a problem of increasing concern. This situation has arisen as a result of the rapid growth of population, increased urbanization, and expansion of industrial activities, exploration and exploitation of natural resources, extension of irrigation and other modern agricultural practices, as well as the lack of enforceable environmental regulations (Biney, Amuzu, and Calamari, 2011)

The major routes of heavy metal uptake by man are food, drinking water and air for example, Aquatic fauna especially fish are the most important source of mercury $(\mathrm{Hg})$. As trace elements some heavy metals (e.g. copper, selenium, Zinc) are essential to maintain the metabolism of the human body. However, at higher concentrations they can lead to poisoning. The heavy metals linked most often to human poisoning are lead $(\mathrm{Pb})$ mercury $(\mathrm{Hg})$, arsenic (As) and Cadmium $(\mathrm{Cd})$. Others including copper $(\mathrm{Cu})$ Zinc $(\mathrm{Zn})$ and Chromium $(\mathrm{Cr})$ are actually required by the body in small amounts, but can also be toxic in larger doses.

Unlike other pollutants like petroleum hydrocarbons and litter which May visibly build up in the environment, trace metals may accumulate, unnoticed, to toxic level. The presence of heavy metals in water can be detrimental to human health and the aquatic ecosystem, a clear instance is seen in the "Mina Mata Disease" which occurred in Japan, caused by mercury poisoning of consumers of fish, from the industrially polluted Mina Mata Bay (Tanko 2009; FEPA 2011).

For effective water pollution control and management, there is a need for a clear understanding of the inputs (loads) distribution and fate of contaminants, especially heavy metals from industrial discharge and other land-based sources into aquatic 
ecosystems. This should be considered together with the possible effects this can cause on humans when such pollutants enter the food chain. The central focus of this paper is thus to analyze the concentration of heavy metal pollutants in River Kaduna and their possible ecological and environmental consequences.

Kaduna State has one of the largest concentrations of industries in Nigeria, which discharge waste water, it is also a rapidly expanding city through urbanization (Amadi, Okoye, Alabi, Tukur, and Angwa, 2014)).This means several activities in addition to industrial discharge of waste water and municipal sludge which may probably contain heavy metal pollutants all of which pass through industrial drains, tributary streams and finally into River Kaduna (KEPA, 2011).

River Kaduna may suffer enormous pollution and may contain high concentration of heavy metals as a result of industrial activities and other anthropogenic sources of contamination, it is thus important to test and analyze the concentration of these heavy metals in the River; this is important, in view of the fact that the River basin serves as a major source of irrigation water for most of the farming activities practiced along the flood plain of the River and aquatic foods such as fish for most of the inhabitants of Kaduna metropolis and beyond. This means there is every possibility of these heavy metals to Bio-accumulate in fishes or plants which eventually can be consumed by humans leading to severe diseases.

Many villages and communities downstream also source their domestic water from the River and the Kaduna south water works source its raw water from the River at the southern axis where industries discharge their waste into the river. This would mean a high cost of purification in terms of treating the water (Aliyu, Saleh and Kabiru 2015).

Kaduna town has one of the largest concentrations of industries in Nigeria, it is also a rapidly expanding city through urbanization. The industries discharged waste water and municipal sludge which may probably contain heavy metal pollutants that pass through industrial drains, tributary streams into River Kaduna.

River Kaduna suffers enormous pollution and may contain high concentration of heavy metals, it is thus important to analyze the concentration of these heavy metals in the River. The River Kaduna is the major source of water for irrigation, fishing, domestic and industrial uses for the inhabitants of the Kaduna town. The river is the major source for the Kaduna
South Water Works. The deadlier diseases like edema of eyelids, tumor, congestion of nasal mucous membranes and pharynx, stuffiness of the head and gastrointestinal, muscular, reproductive, neurological and genetic malfunctions caused by some of these heavy metals have been documented (Mombeshora, Osinbanjo, and Ajayi, 2013). Therefore, monitoring these metals is important for safety assessment of the environment and human health in particular.

The paper determine the concentration of some selected heavy metal of the surface waters of River Kaduna, examine the pollution status of River and the implications of the heavy metal pollution on human health and the environment.

\section{MATERIALS AND METHODS}

The Study Area : Kaduna metropolis has a total land area of about $3,080 \mathrm{~km}^{2}$. It is located between Latitudes $10^{\circ} 52^{\prime}$ and $10^{\circ} 30^{\prime} \mathrm{N}$ and Longitudes $7^{\circ} 15^{\prime}$ and $7^{0} 45^{\prime}$ east (BLSK 2010).

The area is situated on a relatively low plain liable to flood (BLSK 2010). The topography of the area consists of a rolling park-like terrain with little relief situated about one hundred feet $(500 \mathrm{~m})$ above sea level (Adetola, 2000). The soils of the study area fall within the tropical ferruginous soils. The topsoil is coarse sandy loamy to clay loamy (Adetola 2000). The area was initially characterized by over $80 \%$ agricultural land-use. However, owing to the petroleum industry, the land-use pattern is fast changing.

The climate of the study area is part of the tropical wet and dry climate of Nigeria. The climate is characterized by the wet and dry seasons. The wet season begins in April and ends in October. Though, there are fluctuations in the beginning and the ending of the seasons from year to year in some years it begins early may (Adetola, 2000). The area has a mean annual rainfall of about 1204 to $1567 \mathrm{~mm}$, mean daily temperatures of between $27^{\circ} \mathrm{c}$ to $33^{\circ} \mathrm{c}$, and relative humidity of about $99 \%$ during the wet season and less than $55 \%$ in the dry season (Adetola, 2000). The 2006 census estimated the population of Romi area to about 5,830 people.

The river Kaduna took it source from Jos plateau. The river divides the Kaduna metropolis into two major areas, thus: Kaduna north and Kaduna south. The north houses mostly the commercial centers, residences and business activities and the south is mostly the industrial area. 
Sample collection: For this research, five sampling points were chosen along the river Kaduna based on the accessibility. The surface water samples were collected at the mid-stream using Grab method. The collections were done at the depth of $20-30 \mathrm{~cm}$ directly into clean 1 litre plastic bottles at the intervals of two kilometers each. The samples were marked A, B, C, D and E. The samples were collected for two seasons (rainy and dry season). The first samples were collected on the $25^{\text {th }}$ of July and 3th August, 2015 when the volume of the water had increase in the rainy season. Sample A was collected along the Kaduna eastern by-pass, sample $\mathbf{B}$ at Barnawa area, sample $\mathbf{C}$ was collected at Down quarters, sample D was collected at Kakuri - Makera drains and the last sample $\mathbf{E}$ was collected at downstream of Kaduna river at Kudedan. The same procedure of collection of samples was repeated on $28^{\text {th }}$ February and $3^{\text {rd }}$ of March, 2015 when the volume of the water had reduced during the peak of dry season. The samples were immediately taken to the Kaduna State Water Board laboratory for analysis.

Sample Analysis: The collected samples were analyzed for heavy metals of particular interest include lead $(\mathrm{Pb})$ chromium $(\mathrm{Cr})$ Arsenic $(\mathrm{As})$ Iron $(\mathrm{Fe})$, copper $(\mathrm{Cu})$, Berium $(\mathrm{Be})$, Aluminium $(\mathrm{Al})$, Cadmium $(\mathrm{Cd})$, Cyanide and zinc $(\mathrm{Zn})$ which are considered as those very critical for water quality. The Atomic Absorption Spectroscopy (AAS) method was employed in the analyses of the parameters used for the study. The results of the analysis were compared with the World Health Organization (WHO) Water Quality Standard.

Statistical Analysis: The Statistical methods employed for the analysis of the data were frequencies and tables and the results concentration of the heavy metals in the samples were compared with permissible WHO Standards.

\section{RESULTS AND DISCUSSION}

Water Sample Results of the Rainy Season Heavy Metals of River Kaduna: Among the parameters determined is Chromium. The result shows that the concentration of Chromium at all the observed points $\mathrm{A}, \mathrm{B}, \mathrm{C}, \mathrm{D}$ and $\mathrm{E}$ are above the standard limit of WHO. At point $\mathrm{A}$, the value of Chromium was $144 \mathrm{mg} / 1,1.65 \mathrm{mg} / \mathrm{l}$, at $\mathrm{B}$ and at $\mathrm{C}$ is $1.55 \mathrm{mg} / \mathrm{l}$. The value increases at point $D$ and $E$ to $3.72 \mathrm{mg} / 1$ and $3.69 \mathrm{mg} / \mathrm{l}$ respectively due to the addition of metal content from the industrial wastes.
The results of Iron obtained during the rainy season indicate that the values show a progressive increase from point $A$ with the values of $0.976 \mathrm{mg} / \mathrm{l}$ and $0.986 \mathrm{mg} / 1$ at point C. The Samples D and E also shows a sharp increase of $5.20 \mathrm{mg} / 1$ and $2.57 \mathrm{mg} / 1$ at Makera-Kakuri drain and downstream respectively. All these values observed are above $0.3 \mathrm{mg} / \mathrm{l}$ the limit standard of WHO.

Copper values at point $\mathrm{A}, \mathrm{B}$ and $\mathrm{C}$ as observed from the analysis are within the acceptable limit of $1.0 \mathrm{mg} / \mathrm{l}$ of WHO standard. But at point D and $\mathrm{E}$, the values raised to $3.16 \mathrm{mg} / 1$ and $1.22 \mathrm{mg} / \mathrm{l}$ above the $1.0 \mathrm{mg} / 1$ of WHO acceptable limit.

The results of zinc obtained during the rainy season from the analysis indicate that the values at point $\mathrm{A}$, $\mathrm{B}$ and $\mathrm{C}$ are within the accepted limit of $1.0 \mathrm{mg} / \mathrm{l}$ of WHO standard. The values at point D and E did not conform to the standard of $1.00 \mathrm{mg} / \mathrm{l}$ as stipulated by WHO. There is a sharp rise of $2.32 \mathrm{mg} / 1$ and $1.19 \mathrm{mg} / 1$ respectively.

The rainy season samples at point $\mathrm{A}, \mathrm{B}$, and $\mathrm{C}$ shows that Arsenic parameter values are within the acceptable limit of WHO standard except at the point $\mathrm{D}$ and $\mathrm{E}$ where the values are $2.59 \mathrm{mg} / \mathrm{l}$ and $1.01 \mathrm{mg} / \mathrm{l}$ above the accepted limit of WHO.

As observed from the table, the values of lead increases from point $\mathrm{A}$, to the last point $\mathrm{E}$ where the values are above the acceptable limit of WHO standard of $0.1 \mathrm{mg} / 1$.

Cyanide, zinc, aluminum and copper with exception of Iron, were observed to be low and are in agreement with FEPA standard. However their concentrations decreased both upstream and downstream from the discharge point. The iron content of the effluent at discharge point of Kakuri Makera drain ranged from 0.92 to $2.66 \mathrm{mg} / \mathrm{l}$ and was above the FEPA permissible standard. Chromium was not detected in the water samples from the effluent discharge point. However, minute concentration of Chromium was noticed in the effluents discharged. This indicates that little quantity of it was released with the wastewater.

The water sample analyzed indicates that Cadmium and Lead are one of the heavy metals in the river observed to be highly concentrated. 
Table 1: Rainy Season Water Samples along River Kaduna and Kakuri - Makera Drain

\begin{tabular}{|c|c|c|c|c|c|c|c|c|c|c|}
\hline $\mathbf{S} / \mathbf{N}$ & Parameters & $\begin{array}{l}\text { Point } \\
\text { (Bypass) }\end{array}$ & $\mathbf{A}$ & $\begin{array}{l}\text { Point } \\
\text { (Barnawa) }\end{array}$ & B & $\begin{array}{l}\text { Point C } \\
\text { (D/qtrs.) }\end{array}$ & $\begin{array}{l}\text { Point D (Kakuri- } \\
\text { Makera Drains) }\end{array}$ & $\begin{array}{l}\text { Point } \\
\text { (Kudedan) }\end{array}$ & $\mathbf{E}$ & $\begin{array}{l}\text { WHO } \\
\text { Standard }\end{array}$ \\
\hline $\mathbf{1}$ & Chromium (mg/l) & 1.44 & & 1.65 & & 1.55 & 3.72 & 3.69 & & $0.1 \mathrm{mg} / \mathrm{l}$ \\
\hline 2 & $\operatorname{Iron}(\mathrm{mg} / \mathrm{l})$ & 0.976 & & 0.976 & & 0.986 & 5.20 & 2.57 & & $0.3 \mathrm{mg} / 1$ \\
\hline 3 & Copper (mg/l) & 0.502 & & 0.502 & & 0.614 & 3.16 & 1.22 & & $1.0 \mathrm{mg} / \mathrm{l}$ \\
\hline 4 & $\operatorname{Zinc}(\mathrm{mg} / \mathrm{l})$ & 0.408 & & 0.427 & & 0.434 & 2.32 & 1.19 & & $1.0 \mathrm{mg} / 1$ \\
\hline 5 & Arsenic (mg/l) & 0.448 & & 0.467 & & 0.765 & 2.59 & 1.01 & & $0.5 \mathrm{mg} / 1$ \\
\hline 6 & $\operatorname{Lead}(\mathrm{mg} / \mathrm{l})$ & 0.627 & & 0.648 & & 0.765 & 3.67 & 1.45 & & $0.1 \mathrm{mg} / 1$ \\
\hline 7 & Cyanide (mg/l) & 0.0004 & & 0.0014 & & 0.009 & 0.007 & 0.006 & & $0.1 \mathrm{mg} / 1$ \\
\hline 8 & Barium (mg/l) & 3.01 & & 3.2 & & 3.2 & 8.1 & 7.89 & & $0.1 \mathrm{mg} / 1$ \\
\hline 9 & Aluminium (mg/l) & 0.15 & & 0.37 & & 0.37 & 0.14 & .9 & & $0.1 \mathrm{mg} / 1$ \\
\hline 10 & Cadmium(mg/l) & 0.002 & & 0.002 & & 0.03 & 0.2 & 0.01 & & $0.01 \mathrm{mg} / 1$ \\
\hline
\end{tabular}

Water Sample Results of the Dry Season Heavy Metals of River Kaduna: It was observed that the results of the dry season water sample of river Kaduna in the table below

Shows a sharp increase in the concentration of the heavy metal parameters determined. The concentration of chromium in the river Kaduna is observed to be as high as $3.96 \mathrm{mg} / \mathrm{l}$ at Kakuri -

Makera drain and Kudenda above the permissible limit of WHO of $0.1 \mathrm{mg} / \mathrm{l}$. Other parameters observed such as iron, copper, zinc arsenic, lead, Barium Aluminium and Cadmium are highly concentrated in the water sample above the permissible values of WHO standard.

Table 2: Dry Season Water Samples along River Kaduna and Kakuri - Makera Drain

\begin{tabular}{|c|c|c|c|c|c|c|c|c|c|c|}
\hline $\mathbf{S} / \mathbf{N}$ & Parameters & $\begin{array}{l}\text { Point } \\
\text { (Bypass) }\end{array}$ & $\mathbf{A}$ & $\begin{array}{l}\text { Point } \\
\text { (Barnawa) }\end{array}$ & $\mathbf{B}$ & $\begin{array}{l}\text { Point C } \\
\text { (D/qtrs.) }\end{array}$ & $\begin{array}{l}\text { Point D } \text { (Kakuri- } \\
\text { Makera Drains) }\end{array}$ & $\begin{array}{l}\text { Point } \\
\text { (Kudedan) }\end{array}$ & $\mathbf{E}$ & $\begin{array}{l}\text { WHO } \\
\text { Standard } \\
\end{array}$ \\
\hline 1 & Chromium (mg/l) & 1.94 & & 1.76 & & 1.75 & 3.97 & 3.96 & & $0.1 \mathrm{mg} / \mathrm{l}$ \\
\hline 2 & $\operatorname{Iron}(\mathrm{mg} / \mathrm{l})$ & 1.676 & & 1.876 & & 1.986 & 5.45 & 2.95 & & $0.3 \mathrm{mg} / \mathrm{l}$ \\
\hline 3 & Copper (mg/l) & 0.704 & & 0.704 & & 0.714 & 3.61 & 1.42 & & $1.0 \mathrm{mg} / 1$ \\
\hline 4 & $\operatorname{Zinc}(\mathrm{mg} / \mathrm{l})$ & 0.218 & & 0.627 & & 0.644 & 2.43 & 1.20 & & $1.0 \mathrm{mg} / 1$ \\
\hline 5 & Arsenic (mg/l) & 0.648 & & 0.967 & & 0.965 & 2.99 & 1.13 & & $0.5 \mathrm{mg} / \mathrm{l}$ \\
\hline 6 & $\operatorname{Lead}(\mathrm{mg} / \mathrm{l})$ & 0.827 & & 0.828 & & 0.965 & 3.97 & 1.67 & & $0.1 \mathrm{mg} / \mathrm{l}$ \\
\hline 7 & Cyanide (mg/l) & 0.0006 & & 0.0016 & & 0.011 & 0.009 & 0.008 & & $0.1 \mathrm{mg} / 1$ \\
\hline 8 & Barium (mg/l) & 3.42 & & 3.42 & & 3.14 & 8.10 & 7.89 & & $0.1 \mathrm{mg} / 1$ \\
\hline 9 & Aluminium (mg/l) & 0.15 & & 0.77 & & 0.77 & 0.97 & 0.92 & & $0.1 \mathrm{mg} / 1$ \\
\hline 10 & Cadmium(mg/l) & 0.00 & & 0.004 & & 0.04 & 0.3 & 0.11 & & $0.01 \mathrm{mg} / 1$ \\
\hline
\end{tabular}

The results of the water samples presented in table 1 and 2 indicates that the river Kaduna had become polluted by the heavy metals from the several small and heavy industries involved in the activities such as battery and paint manufacturing, petroleum refining and spillage, cement, ceramic products, steel and Iron works which are located in the Kaduna South and the Metropolitan center of Kaduna. These metals are been discharged untreated into the river Kaduna. Tanko (2009) also observed in his study that metal concentrations in surface water and sediments are influenced by input from source, the character of sediments, organic materials, temperature and sometimes the mineral composition of the underlying rock in the area where the surface water is situated.

The river as observed from the results show that despite the $10 \mathrm{~km}$ distance downstream away from the metropolitan, which would have enhanced rapid purification, the heavy metals measured were still high above the permissible limit observed by WHO especially during the dry season when the volume of the river reduces.

Among the heavy metal determined, Chromium was observed to have high values above the permissible limit of WHO of $0.1 \mathrm{mg} / \mathrm{l}$ in the river both in rainy and the dry season. The high content as believed was originated from the Automobile and Dyes industries effluents. Chromium has been known to have cancer, Dermatis and Orica risk when taken into the body system.

The high concentration of Iron, Copper, Zinc and Aluminium in the river both in the rainy and dry season samples is an indication of discharge of high metallic waste into the river. According to Nriagu, (2008), that concentration of iron above $1.0 \mathrm{mg} / \mathrm{l}$ can cause ill health such as gastro intestinal irritation. That iron in rivers above the limit can cause impairment of animals' survival, growth and reproduction due to toxic action of iron compounds 
The high values of Arsenic metal in the river Kaduna as observed in table 1 and 2 is attributed to the rampant use of it for wood treatment to prevent rot And also the common use of pesticides, paints, dyes, soap and drugs. The intake of large quantities of Arsenic pollutants leads to gastro - internal symptoms, severe disturbances of the cardiovascular and central nervous systems and eventually death (Biney et. al. 2001).

Barium at upstream was $3 \mathrm{mg} / \mathrm{l}$ and $8 \mathrm{mg} / \mathrm{l}$ at the discharge point. Sulphate was above the FEPA standard both at upstream, discharge point and $2 \mathrm{~km}$ downstream, but was not found along the $4-6 \mathrm{~km}$ distance downstream. This could be as a result of the fertilizer discharge from the farms along the river. This is very dangerous to the soils, vegetation and human health. The pollutants are in particulates form and when rain falls or wastewater over flooded the farmlands or being irrigated, they sink into the soil to be taken up through the plant xylem tissue. The plant may grow stunted with broad leaves and green leaves but finally with low yield. These may have no much direct effect on the plants but on the consumers that feed on the plants (Yunana, Siaka, and Simon 2012). Fish are also known to harbor these toxic pollutants in their organs. Human consumption of these fish poses some danger for human life (Amin, 2006)).

The water sample analyzed indicates that Cadmium and Lead are one of the heavy metals in the river observed to be highly concentrated. This evidence of concentration of PVC products, colour pigments, several alloys, rechargeable nickel-chromium batteries, anticorrosion agent and phosphate fertilizers dumped into the river from the industries and municipal waste. Inhalation of Cadmium fumes or intake of cadmium particulates can be life threatening and although acute pulmonary effects and deaths to human beings. Tanko (2009) study observed that consumption of rice grown in Cadmium contaminated irrigated water may result to bones and kidney failures.

Considering the fact that irrigation agriculture and fishing is practiced downstream of river Kaduna, these metals can bio-accumulate in fishes and irrigated plants especially lettuce and cabbage which if consumed by humans can also cause serious health implications.

Conclusion And Recommendations: The study clearly indicates that the river Kaduna had become polluted by the heavy metals from the several small and heavy industries involved in the activities such as battery and paint manufacturing, petroleum refining and spillage, cement, ceramic products, steel and Iron works which are located in the Kaduna South and the Metropolitan center of Kaduna.

These heavy metals could be transferred to man through the consumption of fish and crops grown from the river which could pose health hazards because of their cumulative effect in the body.

It is therefore recommended that, the River should be put under surveillance since it is the only source of fresh water in this area.

There is the need for mass education of people on the impact of indiscriminate waste discharge on the water quality, health and environment.

Effort should be made by government and individuals to improve the living standards of the people thereby improving the sanitary quality of the environment.

There should be proper monitoring of effluents, into receiving water, portable water, as an integral part of water management in the rivers to enable verification of whether or not imposed standards and regulations are met.

A regular schedule for sampling tributary streams and the main river Kaduna should be established on the basis of the potential pollution effect of streams water, frequency of the sampling should take into consideration the types of hazards, seasonal flows, storms and other factors which should change during the year and after the data must have been collected.

\section{REFERENCES}

Adetola, K. (1990). Notes and Model Answers on Geography for Secondary School Certificate and G.C.E" revised and enlarge edition.

Aliyu, Saleh and Kabiru (2015). Heavy Metals Pollution on Surface Water Sources in Kaduna

Metropolis, Nigeria. Science World Journal Vol 10 (No 2) 2015 www.scienceworldjournal.org ISSN 1597-6343

Amin, A. M. (2006): Environmental Impact Assessment of Kaduna Refinery on the Rido Region of Kaduna Metropolis (May 2006) Ph.D. Thesis.

Amadi, A,N., Okoye, N,O., Alabi A,D., Tukur, A. and Angwa, E.M.(2014):Quality Assessment of Soil and Groundwater near Kaduna Refinery and Petrochemical, Northwest Nigeria. Journal of Scientific Research \& Reports 3(6): 885-893 
Bureau for Land and Survey Kaduna (2010). Map of Kaduna State Showing the Local Government Areas.

Biney, Ch., A. T. Amuzu, D Calamari T. (2011) “A Review of Heavy metals in the African Aquatic Environment" (yahoo.com/search).

FEPA (2011): Interim Guidelines and Standards for Environmental Pollution Control in Nigeria.

Kaduna State Environmental Protection Authority (1998) Regulation No. 31998 - Effluent Limitation and Management. Regulation No. 2 1998 - Control of Water Pollution Sources.

Mombeshora, c., Osinbanjo, 0., and Ajayi, S. O. (2013). Pollution studies on Nigerian rivers: the onset of lead pollution of surface waters in Ibadan. Environ. Int., 9, 81-84.
Nriagu, 1. o. (2008). Lead in soils, sediments and major rock types. In Nriagu, J. O. (Ed.), The Biogeochemiscry of Lead in cheEnvironment, pp. 15-72, Elsevier/NorthHolland.

Tanko A. I. (2009): Stream Pollution in the Sharada Industrial Area Kano State" unpublished dissertation submitted to Geography Department, BUK. Area Kano State" Unpublished B.sc Dissertation submitted to Geography Department, BUK

Yunana M. A., Siaka S. and Simon, S (2012). .Effects of Refinery and Petrochemical Effluents on the Vegetation of Romi River Area of Kaduna State 